\section{> Gjesteskribent}

\section{Katrine Bråtane}

Sykehusprest

Sunnaas sykehus

\title{
Skam ved plutselig funksjonstap
}

\author{
I en krise etter et plutselig funk- \\ sjonstap er skammen ofte taus og \\ får ikke alltid den oppmerksom- \\ heten den trenger og burde hatt. \\ Som prest ved Sunnaas sykehus \\ har jeg mange pasientsamtaler og \\ vil her ta utgangspunkt i dem.
}

Mange sliter med opplevelsen av å være uten betydning. Etter et plutselig funksjonstap er gjerne denne følelsen forsterket. Dette kan skyldes at tidligere fysiske funksjoner ikke lenger er som de var og at den rammede ikke kan delta i aktiviteter på samme måte som før. Opplevelsen av å være uten betydning vil da kunne bli enda tydeligere. I vårt samfunn er det stort fokus på synlige og praktiske resultater, og det fysiske har ofte størst verdi. De rammede kan derfor lett føle seg uten verdi og betydning. Vi har alle ulike roller, i familien, blant venner og på arbeid, og de fleste av oss har et bilde av hvordan disse skal være. Rollene man tidligere har hatt, kan for mange være vanskelige å fylle på samme måte som før. Når den rammede ikke lenger kan utføre det som forventes i de ulike rollene, vil følelsen av ikke lenger å ha betydning ofte utløses. I en slik krisetilstand er det vanskelig å se alternativer og muligheter. Opplevelsen av maktesløshet leder mange til resignasjon.

M, 26 år, klandret seg selv for det som hadde skjedd. Hvorfor skulle han stupe akkurat der? Han skulle vært mer observant. De hadde vært sammen i et halvt år. Nå var det slutt. Hun hadde ikke sagt noe da han gjorde det slutt. Sannsynligvis var hun lettet. Han hadde sett seg selv i speilet. Han visste hva hun så når hun så på ham. En «krøpling», det var det han var blitt, en ubrukelig en. Aldri kunne han bli den han hadde vært, han kunne jo ikke engang holde rundt henne når hun var lei seg. Stadig oftere i det siste hadde han spurt seg selv om det egentlig var noe poeng å leve lenger? Hvis han var død, var han i hvert fall ikke til bry lenger.

Vi strekker oss alle etter respons og gjensidighet. Skam er opplevelsen av ikke å bli møtt. I mangel på opplevelsen av aksept fra både omgivelsene og seg selv vender den rammede seg mot seg selv. Det er enkelt å anklage samfunnet og menneskene rundt, men ofte er det opplevelsen den rammede har av seg selv som fører til skam. De idealer denne personen har i forhold til de ulike rollene, er med på å avgjøre om vedkommende føler seg betydningsfull eller ikke. Det er denne opplevelsen av uverdighet som er skam. I artikkelen Tapte ansikter sier Finn Skårderud: «Skammens onde sirkel er at det er skammelig å vise fram sin skam, skammen for skammen. Den som opplever angst og sorg, kan oppleve omgivelsenes medfølelse og omsorg. Den skamfulle forventer forakt. Det er den dype skammens dobbelte byrde» (1).

Mannen jeg beskrev over, så seg selv i speilet og dømte ut fra det hvordan kjæresten så på ham. Vi kan ikke vite hvorfor hun ikke sa noe da han gjorde det slutt, men for ham var det en bekreftelse på at han ikke lenger var den samme. Han var blitt annerledes, kanskje til og med ikke verdig hennes kjærlighet. På sin måte viste han sin kjærlighet til henne ved å la henne gå.

Skårderud har sagt at den dypeste form for skamopplevelse er å vise seg frem med sin kjærlighet for så å bli avvist. Dette er en svært sammensatt situasjon, og det finnes ingen enkle svar. Et av de største problemene her er at denne mannen sannsynligvis mer eller mindre bevisst leter etter bekreftelse på at han ikke lenger er verd å elske. At det ikke lenger finnes noe ved ham som er positivt. Han leter etter bekreftelse i folks måte å snakke til ham på eller gjennom kroppsspråket deres, og er kun åpen for det som kan tolkes negativt. Han er så opphengt i det han tror er realiteten at han ikke er åpen for å høre hva som virkelig blir sagt.

I kriser kan det være vanskelig å leve opp til forventninger fra omgivelsene og fra seg selv. Dette kan bidra til at den rammede vender seg mot seg selv med opplevelsen av å være uten betydning. I møtet med pasienter er det viktig å huske på at det usagte ofte kan ha større betydning enn det som faktisk blir sagt. Spesielt når det gjelder skam. Skammen forblir i mange tilfeller taus fordi det, som Skårderud sier, er skammelig å vise frem sin skam.

\section{Pasienthistorien er fiktiv.}

\section{Hratrine Britane}

Litteratur

1. Skårderud F. Tapte ansikter. I: Wyller TE, red. Skam - perspektiver på skam, ære og skamløshet i det moderne. Bergen: Fagbokforlaget, 2001: 40. 